\title{
Planificación urbana posible, imaginario, existencia y cultura
}

Everaldo Batista da Costa*

http://orcid.org/0000-0003-0734-6680

\section{Introducción}

Comprender y confrontar los resultados urbanos y urbanísticos de la globalización, en el modelo productivo capitalista, que simultáneamente genera riqueza y pobreza, requiere la reflexión y la práctica de una planificación territorial que vaya más allá de centralidades exclusivas, límites impermeables y geometría del espacio. Por un lado, las ciudades del mundo globalizado dependen de ajustes o conexiones inter-intrar-regionales para mantenerse; por otro, su comprensión implica leer sus efectos sobre el cuerpo y la mente del sujeto ${ }^{1}$ en lo cotidiano. Este argumento dialoga con Merleau-Ponty (2006), para quien la espacialidad del cuerpo esclarece la percepción del objeto por medio de la percepción del espacio, pues la experiencia del cuerpo propio nos enseña a enraizar el espacio en la existencia.

* Universidade de Brasília, Brasília, Brasil.

1. La noción de sujeto adoptada en este artículo es sartreana, la cual parte del proceso de producción como un todo y se refiere al individuo biológico, psicosomático, donde el individuo, placer-necesidad-trabajo, es él mismo un todo; a partir de esto, las relaciones sociales asimétricas o simétricas, ordenadas por las relaciones con la naturaleza, pueden comenzar a constituir una totalización, y es a partir de esta totalización que podemos tratar de saber, no a priori, sino en la historia misma, en qué condiciones una totalización se pierde (Sartre, 2015, p. 78). 
La idea de una planificación urbana posible ${ }^{2}$ se alinea con las nociones de imaginario, existencia y cultura, ya que incorpora dimensiones de la vida práctica del individuo, apuntando a la ciudadanía plena a través de la equidad socio-territorial (cf. Santos, 2007). Por lo tanto, esta propuesta centrada en el sujeto activo de lo cotidiano busca la ciudad democrática, que se consolidará con la experiencia y la imaginación de quienes se reproducen de acuerdo con las ofertas reales de usos y apropiaciones del territorio, considerando que "una inmensa construcción imaginaria es lo que define la circunstancia de la relación social” (Martins, 1998, p. 4)3. Este enfoque se justifica en dos premisas compuestas:

- Pensar en la planificación como una posibilidad concreta de la vida urbana menos vulnerable requiere precaución epistémica y práctica, ya que las ideas de planifcación, cultura y existencia, juntas, contienen la experiencia imaginativa espacial urbana, que predice las movilizaciones de resistencias sociales ${ }^{4}$ para la mitigación de las desigualdades. El radicalismo centrado en la crítica del Estado y la planificación estratégica parece perder las conexiones inherentes a la vida cotidiana

2. Las concepciones de planificación urbana, de hecho, agregan un campo de saber muy vasto y heterogéneo. Por eso, Villaça (2002, pp. 191-192) sintetiza los cambios de nomenclatura, formas, contenidos y metodologías de los planes (desde la experiencia brasileña). Según el autor, el período de 1930-2000 puede ser dividido en tres etapas: del urbanismo y del plan director (1930-1965), de los Súper-planes (1965-1971) y del "Plan sin Mapa" (1971-1992). En primer lugar, queda en desuso la expresión plan de mejoramientos y embelesamientos (de influencia francesa renacentista del inicio del siglo $\mathrm{xx}$ ), sustituidos por la expresión urbanismo (que nace, en América Latina, asociado con el arte urbano, la arquitectura de las ciudades, a su embelesamiento, otra vez desde Francia). Después, urbanismo queda en desuso, siendo sustituida por planeación urbana y plan director (maestro). Después por plan urbanistico, plan local integrado y finalmente vuelve el plan director (en una creciente que intenta cubrir la expansión del tejido urbano, integrando la ciudad a su región, más allá de su morfología interna, sino incorporando, poco a poco, diferentes problemáticas del vivir en las ciudades). Para Villaça, los contenidos y metodologías de elaboración de los planes sufren cambios radicales. De grandes volúmenes con centenas de páginas, llenas de mapas, investigación y estadísticas elaboradas por equipos multidisciplinares y abordando un gran abanico de problemas, se transforman en simples proyectos de ley, a veces conteniendo solamente declaraciones de principios, políticas o directrices generales, a veces sin mapas, o con pocos mapas. Un simple proyecto de ley publicado por los gobiernos. "El destino de la planificación urbana en el Brasil actual, el perfil, la credibilidad y el contenido de los planes directores están así ligados a los avanzos de la consciencia de clase, de la organización del poder político de las clases populares. Ese es un proceso lento, una vez que, en Brasil, como dice Martins, nuestra historia es lenta, pues es grande el poder del atraso" (Villaça, 2002, pp. 240-241).

3. Todas las traducciones son del autor.

4. La noción de resistencia adoptada aquí significa la duración, la fuerza y las estrategias de los grupos sociales para mantener la vida en el lugar, sobre todo en las ciudades latinoamericanas. Según Cefaï(2009), el horizonte del vivir-junto y del bien-vivir-junto no cesa de reconfigurarse al confrontarse con actos de resistencia, protestas, desobediencia y crítica, de denuncia y reivindicación, o sencillamente, sin llevar necesariamente esa valencia negativa, de investigación, experimentación, cooperación e innovación. 
genuina, activa e imaginada. Además de la denuncia a la producción, al consumo y a las vulnerabilidades sociales, el pensamiento y la práctica de la planificación urbana deben agregar percepciones, gustos, afectos, creencias, temores, necesidades reales o logros populares cotidianos en el trabajo, la política, la religión, el ocio, los conflictos, construyendo una geografia social imaginativa del lugar.

- La planificación estratégica totalitaria (ordenada por la razón mecanicista) tiende a esterilizar la cultura y los múltiples significados de la existencia y experiencia urbana. Sin embargo, la investigación, los planes maestros, el uso de la tierra y las leyes de ocupación deberían resaltar el conocimiento de los sujetos que, colectiva y emocionalmente, constituyen territorios populares, centros nuevos o viejos. Hay investigaciones sociales e instituciones que tienden a revelar la vulnerabilidad de los habitantes de barrios subalternizados, generalmente reconociéndolos como marginales, abstrayendo nociones de sujeto, clases o lucha de clases, lugares de poder y control, relaciones de producción, población, sociedad, nación, porque desconocen al individuo y sus dramas junto con sus facultades de existencia. El uso de estas nociones, sin investigación social rigurosa que adopte métodos y metodologías de las ciencias humanas, puede disminuir u omitir, en el discurso y la práctica, el valor de las resistencias situadas, las posibilidades reales de la planificación técnica oficial y de cartografías imaginativas (o representaciones espaciales fenomenológicas y dialécticas de bienes o vulnerabilidades in situ).

Así, el objetivo de este artículo es proponer el imaginario, la existencia y la cultura como una triada operativa de una planificación urbana posible. Situar a los sujetos que realizan lo cotidiano en la ciudad (en su totalidad y totalización) $)^{5}$, que la perciben y la construyen desde sus lugares de tránsito y permanencia. Teórico-metodológicamente, se presentan escalas de planificación dependentes de imaginarios cuya ontología debería debatirse e incorporarse más; son consideradas (i) la racionalidad instrumental de la planificación; (ii) su tríada categórica operativa (cultura, existencia e imaginario); y (iii) elementos de su geografía social imaginativa.

Una tesis considerable es que la teoría urbana radical (cuyo arsenal conceptual tiende a abstraer la realidad, si no se acompaña de una sistemática investigación empírica), al tratar de abarcar generalidades y universalidades gobernadas por sus conceptos, pierde las singularidades y matices urbanos propias de la resistencia histórica de los grupos subalternizados en el lugar, que puede revisarse reconociendo la predicción dialéctica del imaginario urbano. Singularidades que contienen la totalidad

5. La totalidad concreta es la categoría filosófica de la verdad empleada por K. Marx, K. Kosik, G. Luckács, H. Lefebvre, etc. 


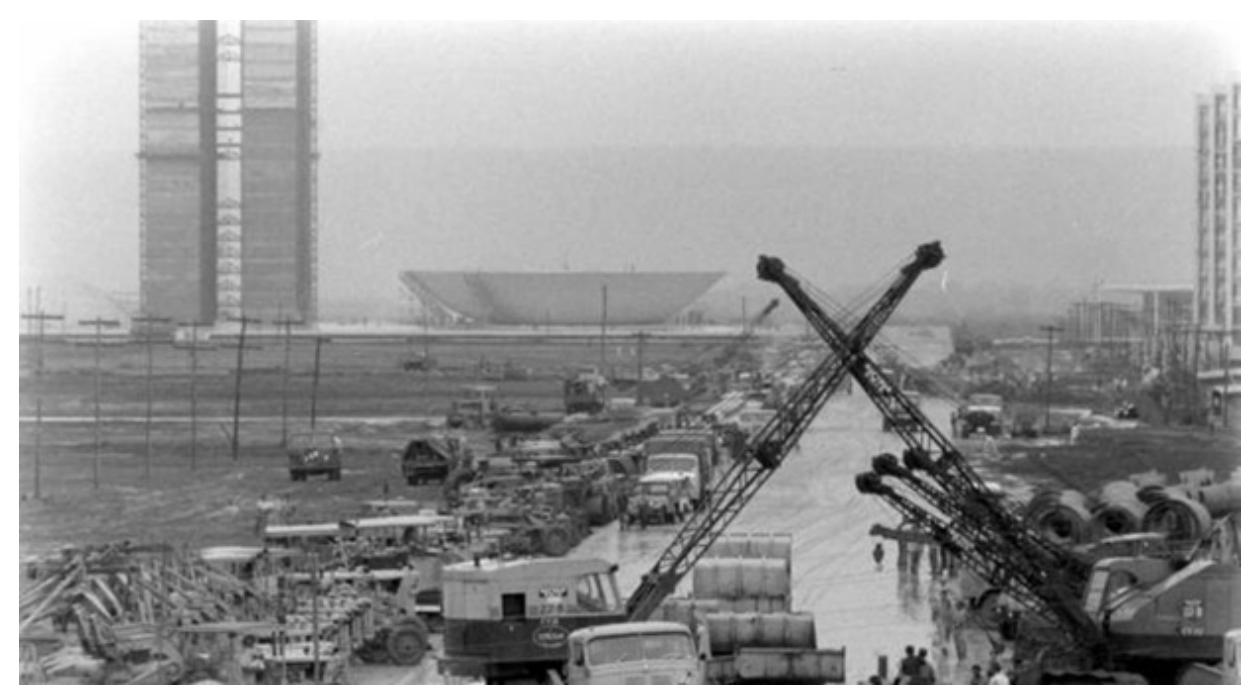

Figura 1: Construcción del Plano Piloto de Brasilia (Esplanada dos Ministérios), década de 1950. Fuente: Arquivo Público do Distrito Federal.

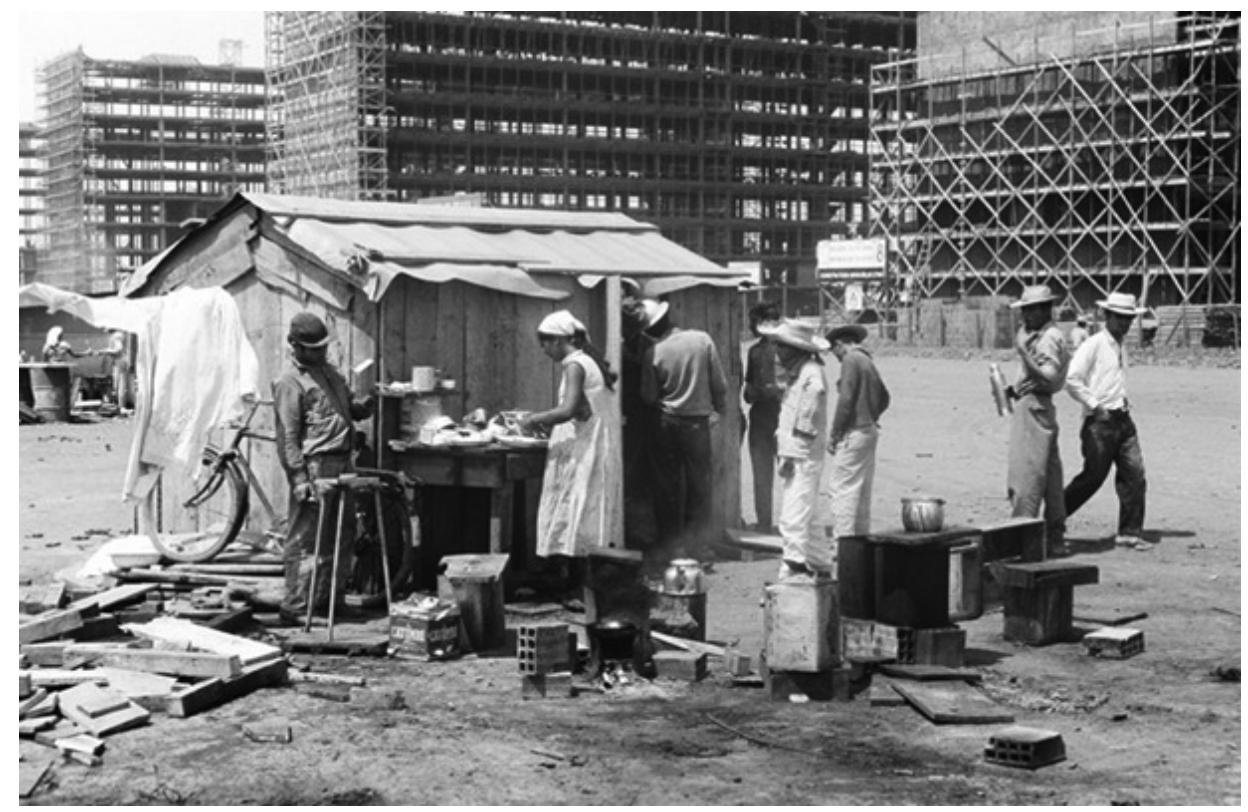

Figura 2: Trabajadores migrantes en el almuerzo en la Explanada de los Ministerios, antes de la inauguración de la nueva capital, década de 1950

Fuente: Arquivo Público do Distrito Federal. 
concreta de la experiencia urbana, que pasa de habitar y trasladarse a trabajar, de vivenciar y de percibir a sufrir, de alegrarse o emocionarse en el sitio, de consumir, de producir y de reproducirse en los lugares, de vivir, de existir y de morir en la ciudad ${ }^{6}$.

Hay que adelantar, esta lectura de una planificación urbana posible (integradora del sujeto, su existencia y experiencia, de sesgo latinoamericano) no está incluida en el rol de los "estudios culturales urbanos" llenos de confusiones conceptuales e imprecisiones políticas, criticados por Gorelik (2002). El autor argumenta que los estudios socio-semióticos sobre identidades e imaginarios urbanos, cuyos temas pueden ser, por ejemplo, los colores o los olores con que la gente identifica a sus ciudades o los sentidos múltiples de los graffiti populares, está siendo crecientemente requerido por gobiernos municipales como instrumento técnico para sus políticas; Gorelik no refuta la realización de los estudios en sí, pues algunos aportan al conocimiento de la sociedad, sino que señala la novedad que en muchos casos ocupan las políticas municipales: un reemplazo de la imaginación política por las opiniones (o los deseos) "de la gente", estadísticamente relevantes para atender al mercado global de ciudades. Para Gorelik (2002), se han desvanecido los límites entre marketing y política, y la noción de marketing urbano gana adeptos como única alternativa de política de ciudad en tiempos de globalización.

Por otra vía (humanista-crítica-existencialista), este artícuo teórico-metodológico argumenta la abstracción y la concreción de la población o el ciudadano de sectores específicos de la ciudad, desde dónde se cuestiona y cómo se entiende, frente a problemas y potenciales pasados y presentes en $s u$ vida urbana situada. Esta evaluación requiere una epistemología tributaria de una economía política de la ciudad que nunca prescinda de la existencia objetiva e imaginativa del sujeto. Dicha epistemología dialoga con la ontología del imaginario de C. Castoriadis, con la teoría de la existencia de J. P. Sartre, se nutre del debate crítico frankfurtiano de la cultural, además de incorporar una reflexión más reciente sobre las ciudades (correspondiente a la experiencia del autor con investigaciones urbanas en diferentes países de América Latina).

Racionalidad instrumental de la planificación y predicción dialéctica del imaginario

Los análisis críticos sociológicos y geográficos asocian el concepto de "racionalidad" con la "actividad económica capitalista" y con el "control normativo" del

6. A pesar del enfoque del texto en la ciudad, el a priori reconocido es el de la fricción, la simbiosis y la tensión que constituyen la ciudad-campo o lo rural-urbano en tanto devenir, en Latinoamérica (Alvarado \& Costa, 2019). 


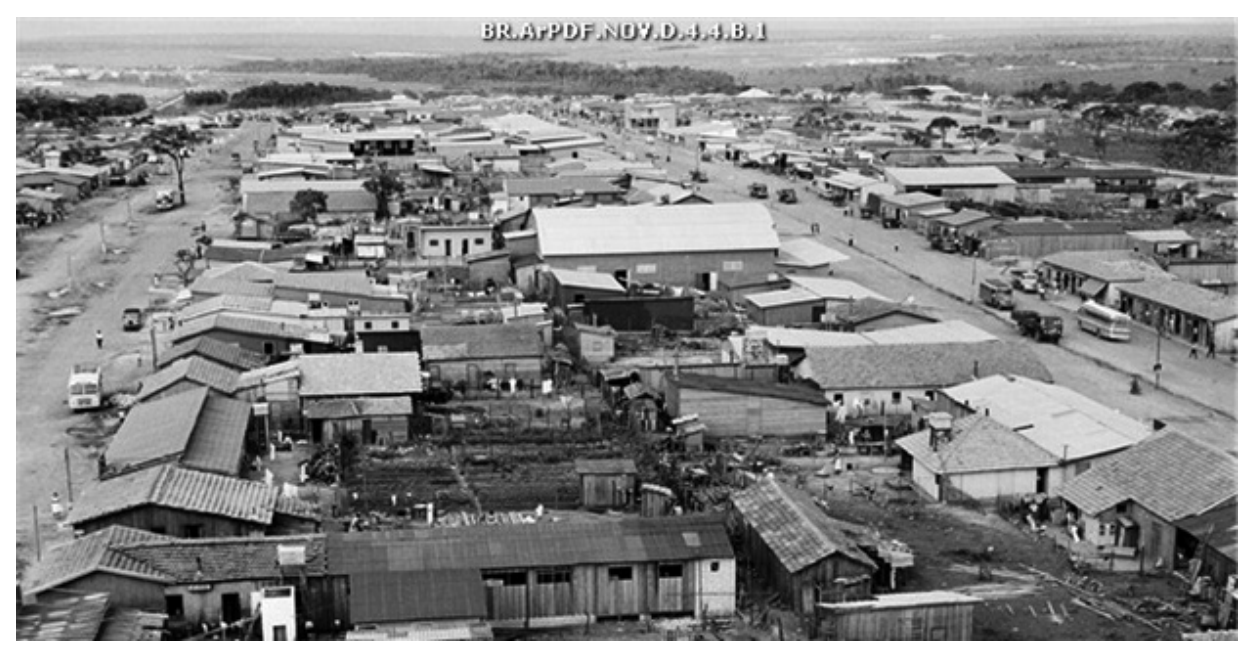

Figura 3: Núcleo Bandeirante (irregular), ciudad levantada junto con la construcción de Brasilia, década de 1960. Fuente: Arquivo Público do Distrito Federal.

territorio. Esta visión resulta de la industrialización del trabajo social, donde los criterios de acción instrumental alcanzan otras áreas de la vida, como la urbanización de las formas de existencia, la tecnificación de la movilidad y la comunicación, relativizando lo cercano y lo distante, afectando el cuerpo y la mente del ciudadano urbano, despersonalizándolo (cf. Habermas, 1968; Santos, 2008b; Matos, 2010).

Esta instrumentalización de relativa humanización, que distingue la política orientada a los ciudadanos del contenido político de la tecno-ciencia o la técnica, está anclada en el Estado hegeliano: síntesis absoluta, coercitiva, racional, de "conocimiento" y "conciencia colectiva", la deidad misma o una "Ideia" (cf. Lefebvre, 2010). Se reúne en el orden político lo que pareciera espontáneo (los oficios, la familia, el trabajo, el ocio, la vida cotidiana ${ }^{7}$ ), de manera que existe una minoría o la clase media y la clase hegemónica político-económica, la cual dirige el Estado, con su propia conciencia y cultura ${ }^{8}$. Así, la planificación y la gestión son acciones racionales que, dirigidas de manera exclusiva, llegan a todos los ciudadanos de manera desigual: el estable-

7. Lefebvre (1968) divide lo cotidiano en tres tiempos: el tiempo de trabajo, el tiempo libre, el tiempo constreñido o dedicado a las diversas exigencias más allá del trabajo. Para el autor, lo cotidiano y la modernidad son aristas del espíritu del tiempo dirigidas por la ciudad moderna, lugar por excelencia de la institución de la vida cotidiana (centro real de la praxis).

8. La crisis política experimentada por Brasil, después de 2016 (desde el juicio político de Dilma Rousseff hasta el ascenso al poder de Jair Bolsonaro), revela el dominio de estas clases desde el centro sur del país. Clases de alto grado de astucia ideológica para el control social, con el fin de acelerar el dominio popular por parte de esta clase política, controlar los lugares y la fuerza del saber popular y re-direccionar la división del trabajo y el comando del territorio brasileño. 
cimiento, la mejora, la expansión o la negación de los sistemas de acción racional, de los servicios técnicos territoriales urbanos. El Estado y la planificación, en este ámbito, no deben trivializarse, sino asimilarse en una reacción colectiva por demandas, situándolos en su evidente papel social. Además, la acción u omisión estatal en el control territorial estimula la sociedad de riesgos, en la que su ausencia-presencia (estatal) democratiza los efectos de los peligros y vulnerabilidades?.

La racionalización progresiva de la sociedad se basa en la institucionalización del progreso científico y técnico; las antiguas legitimaciones sociales (y naturales) se derriban en nombre de la racionalización de las técnicas y una tendencia a la catástrofe de las significaciones (cf. Adorno, 2009; Habermas, 1968; Matos, 2010). El desafío es entender esta racionalización como generadora interna de una praxis cultural y existencial que perpetúan la vida espacial de los sujetos subalternizados, la contrar-racionalidad. Debemos eludir la furia técnica y mecánica modernas que oscurece la humanización de lo y en lo planificado, sin negar la política y el Estado, pero interpretándolos, pues la racionalidad de la planificación conlleva una dominación política multiescalar convergente-divergente no inmediatizada en el territorio. Las estrategias se ejecutan gracias a un aparato técnico dispuesto y a una acción técnica racional dirigida al ejercicio del control capitalista (Habermas, 1968), de modo que el imaginario es el guardián de su adversario, la contra-racionalidad popular. "La modernidad es la inmersión cada vez más profunda en la materia, es atrofia del espíritu y pérdida colectiva de la reina de las facultades, la imaginación" (Matos, 2010, p. 158).

En este sentido, la predicción dialéctica del imaginario es definida como la acción cruzada de dos racionalidades de diferentes grados y orígenes, la de la planificación económico-mecanicista y la de la resistencia popular situada, viviendo desequilibrada, paradójica, pero mutuamente. Este imaginario predice o presagia la praxis o transformación de la realidad, ya que explica la historia humana, unifica a la sociedad, proporciona contenido entrelazado con estructuras simbólicas, niega la idea ilusoria de la progresión instantánea del orden racional, acusa los problemas de las dimensiones existenciales y contiene los elementos esenciales para una cartografía de los afectos ${ }^{10}$.

9. Ver Beck (2010) y Costa (2018) para cuestiones sobre los efectos democráticos del riesgo, respectivamente, en el mundo y en Latinoamérica.

10. En Costa \& Alvarado (2019) fue trabajada la facultad de predicción del imaginario creado y difundido (o de la intencionalidad imaginativa), balizador y entidad de preservación patrimonial. En Noel Lapoujade (2011), Hiernaux (2007), Silva (2014) y Costa \& Peluso (2016) también se identifica una lectura operativa del imaginario. Para Hiernaux (2007), aún está pendiente la tarea de construir un verdadero amarre entre las prácticas y los imaginarios. Pero, hay que evitar trabajos paradójicos, donde "los imaginarios urbanos parezcan producirse en una multiplicidad de territorios en los cuales cada sujeto (individual o colectivo) construye formas de identidad liberadas y liberadoras y, con pocos 


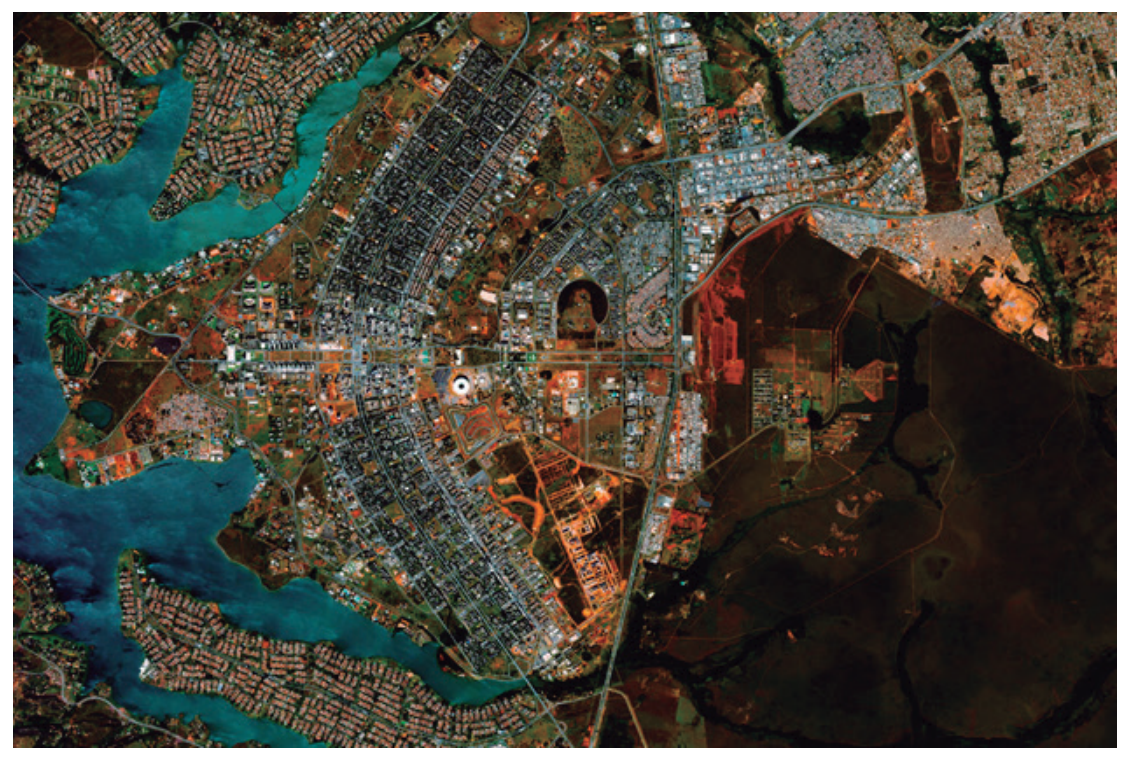

Figura 4: Fotografía aérea del Plano Piloto de Brasilia. Centro planeado del Distrito Federal. Fuente: Instituto Nacional de Pesquisas Espaciais - inpe, 2019.

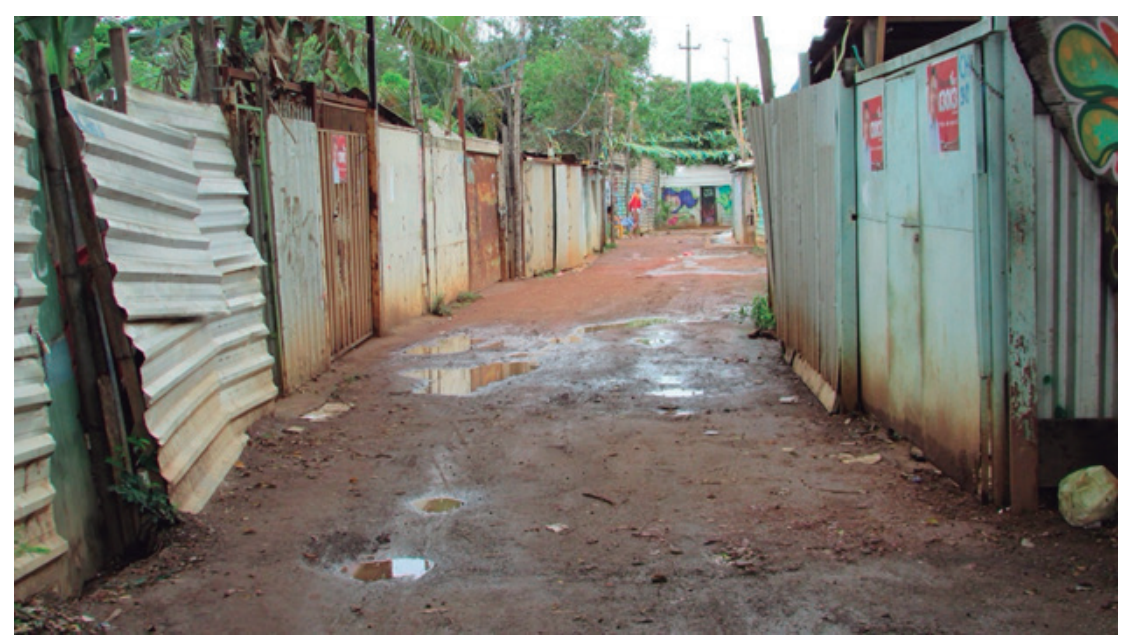

Figura 5: Calle y viviendas precarias en la Villa del Sosiego, Candangolândia, Distrito Federal, Brasil. Fuente: Acervo del autor, 2018. 
"Allí surge un sentido [...] que no es de lo real referido a lo percibido, que tampoco es racional, o positivamente irracional, que no es ni verdadero ni falso y, sin embargo, es del orden del significado, y ésa es la creación imaginaria propia de la historia, qué y de qué se constituye la historia para empezar" (Castoriadis, 1982, p. 192).

La construcción de Brasilia ejemplifica la predicción dialéctica del imaginario, al coexistir la racionalidad de la planificación (figura 1) y la resistencia popular a la segregación violenta (figura 2). La reacción surgió de la propia racionalidad instrumental de planificación del territorio nacional impuesta a la nueva capital, la cual resultó en luchas y modos de organización territorial propios de los trabajadores migrantes; todo sucedido durante los movimientos políticos de fijación en el nuevo sitio, rechazando el orden gubernamental de retorno de los trabajadores a sus tierras de origen (figura 3). Esta ciudad reproduce un híbrido urbano cuyo contenido multi-escalar se compone por la tríada modernidad (continuum de la era productiva basada en el individuo, esto también como producto), modernismo (forma artístico-arquitectónica) y modernización (concepción técnica del desarrollo encarnado en la ciudad aséptica y racionalidad del Estado demiurgo de la sociedad); tríada propia de las nuevas (también antiguas) ciudades latinoamericanas de mediados del siglo $\mathrm{xx}$, que consagraron la idea de la aceleración de la modernización en el contexto de subdesarrollo" . Brasilia nace como una utopía anclada en un claro imaginario para sus creadores, que proviene del significado atribuido a la modernidad, la sociedad y el urbanismo brasileños a mediados del siglo xx. La capital, más que una ciudad, sería el símbolo de una nacionalidad que caminaba en dirección de grandioso futuro" (Costa \& Peluso, 2016, p. 10).

La ciencia y la técnica reproducen la ideología de la racionalidad y ocultan su control político y la violencia inherentes, que afectan la psique del individuo urbano, con enfermedades tanto físicas como mentales causadas por el ritmo, los excesos y las imágenes relacionadas. El aparato burocrático del Estado (ministerios y secretarías gubernamentales, bancos públicos y privados, la universidad [o en lo que se ha convertido], agencias reguladoras, etc.) parece, pero no es ciego frente al sujeto que realiza y se organiza en la vida cotidiana, éste es un componente real en todas las escalas del territorio. En el centro de una coerción popular consentida y la narrativa de la dignidad socioespacial, la productividad creciente y el dominio técnico de la naturaleza no sólo desplazan al sujeto del plano de la vida inmediata a la esfera del consumo dirigido (con-

párrafos de diferencia, el espacio-poder gana una completa determinación sobre los sujetos, con lo cual los imaginarios urbanos quedan redefinidos como mecanismos ideológicos de la manipulación.” (Gorelik, 2002, p. 06).

11. Sobre este debate a profundidad véase Freitag-Rouanet (2000), Gorelik (2005), Costa \& Steinke (2014), Costa \& Peluso (2016), Costa \& Alvarado (2019); Moura \& Januzzi (2019). 
figurándolo como virtual-abstracto), sino que además se enfrenta en contraposición de los imaginarios populares de resistencia. Justamente por la racionalización extrema del mundo moderno, la cual depende, en principio, del imaginario.

La racionalidad de la sociedad moderna es simplemente la forma, las conexiones externas necesarias, el dominio perpetuo del silogismo. Pero en estos silogismos de la vida moderna, las premisas toman su contenido de lo imaginario. Es la prevalencia del silogismo como tal, la obsesión con la racionalidad aparte del resto, es un imaginario de segundo grado. La pseudo-racionalidad moderna es una de las formas históricas de lo imaginario; es arbitrario en sus fines en la medida en que no dependen de ninguna razón, y es arbitrario cuando se mueve como un fin, buscando sólo una racionalización formal y vacía (Castoriadis, 1982, p. 188).

La hibridación de la vida socioespacial y cultural (a través de la técnica) es gradual y permanente. "Primero, se fortalecieron y reemplazaron las funciones del aparato locomotor (manos y piernas); luego la producción de energía (el cuerpo humano), luego las funciones del aparato sensorial (ojos, oídos, piel) y finalmente las funciones del centro de control (cerebro)" (Habermas, 1968, p. 52).

La teoría crítica y la economía política consideran que, con el aparato técnico total y potencialmente omnipresente, quizás el tema nunca haya sido tan frágil, débil y fuera de lugar -lo que sugiere una relativa alienación social de la idea del progreso técnico e incluso del poder ligado a la normativización privada del territorio. En este sentido, Brasilia racionalmente imaginada y planificada (figura 4) vuelve a ser ejemplar, ya que "marca la inserción del país en el escenario internacional, lo cual logró con éxito gracias a dos elementos conectados: i) forjado de un imaginario nacional por medio de una plegaria desarrollista ininterrumpida; ii) realización concreta de las obras de infraestructura que el país necesitaba, mínimamente, para el desarrollo económico” (Costa \& Alvarado, 2019, p. 20). Es en este contexto que deben recuperarse los instrumentos de planificación, para hacerla posible dentro de propuestas metodológicas centradas en los sujetos que experimentan, viven y mueren en el territorio y sus lugares, recuperándolo y valorándolo en la vida cotidiana, reflexionando sobre la ciudad y $s u$ sitio, dirigiendo a académicos, técnicos y gobernantes hacia los problemas relacionados con $s u$ vida socioespacial y, al mismo tiempo, alcanzando la esencia contradictoria de la racionalidad instrumental (figura 5). "En su actividad, la imaginación puede fungir como catalizador de la razón y en ocasiones puede desprenderse de su tutela" (Noel Lapoujade, 2011, p. 243).

Este debate revela las tendencias espaciales y la segmentación entre grupos sociales o clases en las ciudades; indica, en general y específicamente, los fragmentos de la periferia en el centro y la centralidad de las periferias renovadas, incluso en los nuevos 
órdenes urbanos. Sin embargo, es urgente proponer metodologías que consideren o partan del conocimiento y las necesidades específicas de sujetos concretos. El análisis del sistema capitalista, sus variantes espaciales y sus contradicciones sociales revelan parte de la vida cotidiana de los sujetos, tendiendo a abstraerlos. La economía, en su sentido más amplio (de la producción al consumo), no es sólo expresión por excelencia de la racionalidad del capitalismo y sociedades modernas, sino que sorprendentemente pone a la vista la primacía de lo imaginario en todos los niveles (cf. Castoriadis 1982).

Los códigos de construcción y la zonificación surgen de una concepción práctica y teórica de las ciudades (llamada urbanismo técnico-sectorial), que propuso instrumentos técnicos para mejorar la racionalidad de la organización espacial urbana y las cualidades estéticas -un urbanismo sanitario que evolucionó hacia el urbanismo político-globalizador simplista (Campos Filho, 1989) ${ }^{12}$. El desafío a la racionalidad técnica urbanista es incorporar la totalidad social del proceso de urbanización, creando las condiciones para asumir al sujeto en situación espacial duradera ${ }^{13}$ como la escala de planificación más relevante. Constituir un urbanismo basado en las necesidades reveladas por quienes experimentan, en la vida cotidiana, los dramas y las posibilidades territoriales en el péndulo espacial periferia-centro-periferia, parece el camino propicio para escapar de la abstracción o generalización de la ciudad legal-ilegal, formal-informal, planificada-espontánea. "Reemplazar, en el caso del trabajador, el hombre empleado por un conjunto de características parciales elegidas arbitrariamente, en función de un sistema arbitrario de fines y por referencia a una pseudo conceptualización igualmente arbitraria, y tratarla en la práctica, en consecuencia, refleja una prevalencia de lo imaginario" (Castoriadis, 1982, p. 189).

12. Villaça (2002, p. 191) señala el significado o el contenido de la planificación urbana en Europa o Estados Unidos y Brasil. Allá, al revés de este último, la planificación corresponde, en parte, a la acción concreta del Estado, lo que conduce a Gottdiener decir que "la planificación urbana en toda la sociedad es una fachada para el poder". La cuestión es que este poder, en cada sociedad, cambia su influencia sobre los planes. "Creemos que esa fachada sea totalmente diferente, de un lado, en Brasil en las últimas décadas, en la democracia o en la dictadura y, de otro, en las democracias europeas o de Norteamérica”. En estas últimas, la planificación legitima acciones concretas del Estado, pues en ellas hay correspondencia entre ambos; en Brasil no, siendo apenas discurso, la planificación es una fachada ideológica, que no legitimando acciones concretas del Estado, sino, al revés, buscando ocultarlas. Lo que hay de común en ambos los casos es que está por detrás de la fachada de la planificación urbana el poder, la dominación. Entre ellos, la grantediferencia está en los niveles de hegemonía, aceptación y credibilidad de ese poder (Villaça, 2002).

13. Costa (2016) propone esta noción que denuncia la continuidad secular del dominio estatal y la resistencia social popular en los territorios de segregación de América Latina y el Caribe, por medio del arte, de la religión, de las alternativas económicas, de los movimientos sociales o de la política hecha en el sitio y en escalas. 
El estudio sociológico y geográfico actual de la ciudad requiere teorías y metodologías que anuncien el mundo nuevo ${ }^{14}$, a veces cuestionando, a veces exigido:

- Los casos en que los problemas públicos suelen ser problemas privados de figuras públicas (Bauman \& Donskis, 2014). Las crisis mundiales que inauguran el siglo XXI son de las agencias financieras, que las transfieren a los consumidores, demostrando ser una crisis social global impulsada y catalizada en las ciudades por la fuerza del imaginario mercantil.

- La tecnología que redefine la política y el control del territorio, incorporando la narrativa del bien común. El agente del proceso son las redes sociales que producen la realidad virtual operada e imaginada como realidad concreta.

- El poder individualizante de las imágenes, que lanza y hunde la publicidad de lo absoluto a cero ${ }^{15}$, con respecto a los problemas urbanos [la estética se superpone a la ética de la y en la urbanización, buscando borrar imágenes contrarracionales].

- Una epistemología del desarrollo que prevea la utopía de la autonomía, justicia y libertad social, en detrimento de la racionalidad instrumental del territorio.

- La producción política y en serie de riesgos, con cálculos exactos para ganancias individualizadas y pérdidas democratizadas.

- Ciudades constituidas por viejas y nuevas órdenes de la sociedad de consumo, que salta de la satisfacción de las necesidades primarias a la producción de lo superfluo y la estimulación de los deseos (Bauman, 2013).

- La información universal, que es la base del intento de controlar la imaginación colectiva, forzando la alienación política frente al lugar y la técnica.

- Los elementos transgresivos del orden espacial dominante. Este camino analítico y de praxis se apoya en (i) el orden cultural y existencial conductores de resistencias o movilizaciones, (ii) la ciudad leída como un hecho socioespacial total, memoria individual y colectiva, (iii) la urbanización estudiada como un fenómeno productivo y emocionalmente violento, explicado en la estructura de lo imaginario. Como dice Castoriadis (1982), tratar a un individuo como una cosa o como un sistema mecánico puro no es menos, sino más imaginario.

14. Para M. Santos, el mundo nuevo no será (o no es) una construcción desde arriba, como la que se asiste hoy, sino que su edificación tendrá una trayectória que será de abajo hacia arriba, con un nuevo modelo económico, social y político que posibilite una nueva distribución de bienes y servicios, conduzca a la realización de una vida colectiva solidaria y, pasando de la esala del lugar a la escala del planeta, asegure una reforma del mundo, por intermedio de otra manera de realizar la globalización (Santos, 2009).

15. Baudrillard (1991) analiza la dimensión de las simulaciones producidas en publicidad, que interactúa con lo social. 
La sociología y geografía urbanas deben (i) profundizar la lectura crítica de la racionalidad de la planificación, propia de los tecnócratas basados en instituciones gubernamentales, para construir propuestas multiescalares vinculadas a la imaginación popular; (ii) colaborar con la resistencia urbana, cuando esta racionalidad imaginada y operada revela el carácter racional-totalitario del Estado de dominación social por el espacio; (iii) comprender la constitución burocrática del Estado y participar críticamente en la burocracia, para facilitar la actuación popular en la toma de decisiones y establecer reglas de intervención urbana centradas en la percepción e imaginación del sujeto, porque, como argumenta C. Castoriadis, el universo racional-burocrático está poblado por lo imaginario de punta a punta.

Imaginario, existencia y cultura: tríada operativa categórica de planificación

El imaginario aquí no significa "imagen de", sino creación incesante y esencialmente indeterminada (social-historica y psíquica) de figuras/formas/imágenes, a partir de las cuales solamente es posible hablar de "alguna cosa"; lo principal: aquello que se denomina "realidad" y "racionalidad" son productos del imaginario, ya que todo pensamiento de la sociedad y de la historia pertenece, en sí mismo, a la sociedad y a la historia (cf. Castoriadis, 1982). La existencia asumida es sartreana, de corte marxista (no metafísica): no hay sino indivíduos y relaciones sociales entre ellos, donde el grupo social significa una multiplicidad de relaciones y de relaciones entre esas relaciones; asume el principio de la primacía de la existencia sobre la conciencia, en el que individuo primero existe, se descubre, surge en el mundo, solo despues se define (cf. Sartre, 2002) ${ }^{16}$. Por último y alineada con la matriz filosófica marxista de las definiciones de imaginario y existencia, la concepción marcuseana de cultura es defendida como un complejo de valores morales, intelectuales, materiales y estéticos, que dan sentido a una sociedad (cf. Marcuse, 1998).

En las últimas décadas, ha habido un cambio significativo en los debates sociales sobre las ciudades. De las denuncias a las formas de vida metropolitanas, en la década de 1980 (con imágenes de barrios empobrecidos, tráfico vehicular, contaminación, violencia), en la década de 1990, son evidenciados el urbanismo globalizado, los proyectos de reurbanización, las metrópolis como espacios para comprensión de la globalización, vínculos entre el lugar y el mundo; en la actualidad, los científicos incluyen el problema de la modernidad en la agenda del imaginario urbano y del espacio

16. Eso lo distingue del idealismo hegeliano, que tiene en la conciencia del individuo el núcleo del debate de la existencia (subjetivismo idealista); concepción que conduce toda la crítica marxista del siglo xx a la fenomenología y al existencialismo en general. 
público. Para Gorelik (2005), esta nueva fase de gran productividad no desarrolla ningun tipo de dialogo con la tradición del anterior pensamiento sobre la planificación, incluso sepultando su monumental intensión crítica; lo que este artículo refuta.

Ya fue muy debatido por los científicos sociales y urbanistas que la globalización crea ciudades que están fuertemente divididas, con sectores elitizados "aislados" y economías y culturas "apartadas" en barrios no considerados por las estrategias financieras urbanas globales (cf. Sennett, 1998; Villaça, 2002; Santos, 2008a). Pero, hay que considerar la fragmentación articulada o interdependencia duradera entre los sectores enriquecidos y empobrecidos de las ciudades, pues la trama constituyente del fenómeno urbano posee una complejidad tal que demanda ser revelada a través del sujeto en su cotidianeidad.

Se asume que las grandes ciudades son locus de economía y cultura globalizadas; espacios producidos por los sectores terciario y cuaternario; centros para la reproducción y difusión del arte como negocio; sede de poderosas compañías editoriales y de entretenimiento, grandes bancos y corporaciones (cf. Santos, 2008b; Canclini, 2003). Hoy, los científicos sociales siguen trabajando estos amplios temas y agregan debates peculiares como: la vida de barrio, expresiones de los jóvenes periferizados, trabajo femenino, violencia de género, desarrollo de formas culturales urbanas etc., reconociendo la diversidad inherente a la ciudad y la importancia de comprender la situación de los sujetos en la vida cotidiana y el lugar del sentido común en la investigación social (cf. Martins, 1998; Magnani, 2005; Costa, 2016).

Aunque la vida cotidiana sea el mundo que atribuye sentido a los demás, en tanto referente, aparece subvertida y cambiada en eses otros mundos; lo que nos enseña las discontinuidades que atraviesa la vida cotidiana todos los días (Martins, 1998). Los estudios de las intervenciones urbanas, del patrimonio, de la memoria, del turismo, de los centros antiguos y nuevos indican el éxito de la planificación estratégica más centrada en los hechos urbanos, pero menos en la multiplicidad de experiencias emocionales del sujeto en lo cotidiano. Según J. P. Sartre, el sujeto no es sólo como está concebido, sino como quiere ser, como se concibe y desea a sí mismo después de un impulso a la existencia; el sujeto no es más que lo que hace en su cotidiano. Este primer principio del existencialismo sartreano ayuda a discutir la posible planificación (centrándose en el individuo existente y reconociéndose a sí mismo como localizado y responsable de su proyecto).

¿En qué medida, por ejemplo, los nuevos desarrollos de viviendas de interés social, a menudo segregados de las áreas de la ciudad cubiertas por infraestructura, comercio y servicios, están diseñados para satisfacer las necesidades del demandante existente? A veces parece que se ha perdido el tren de la historia, que transportaba la emoción como la totalidad de la conciencia, de la existencia, de la realidad humana. En otro 

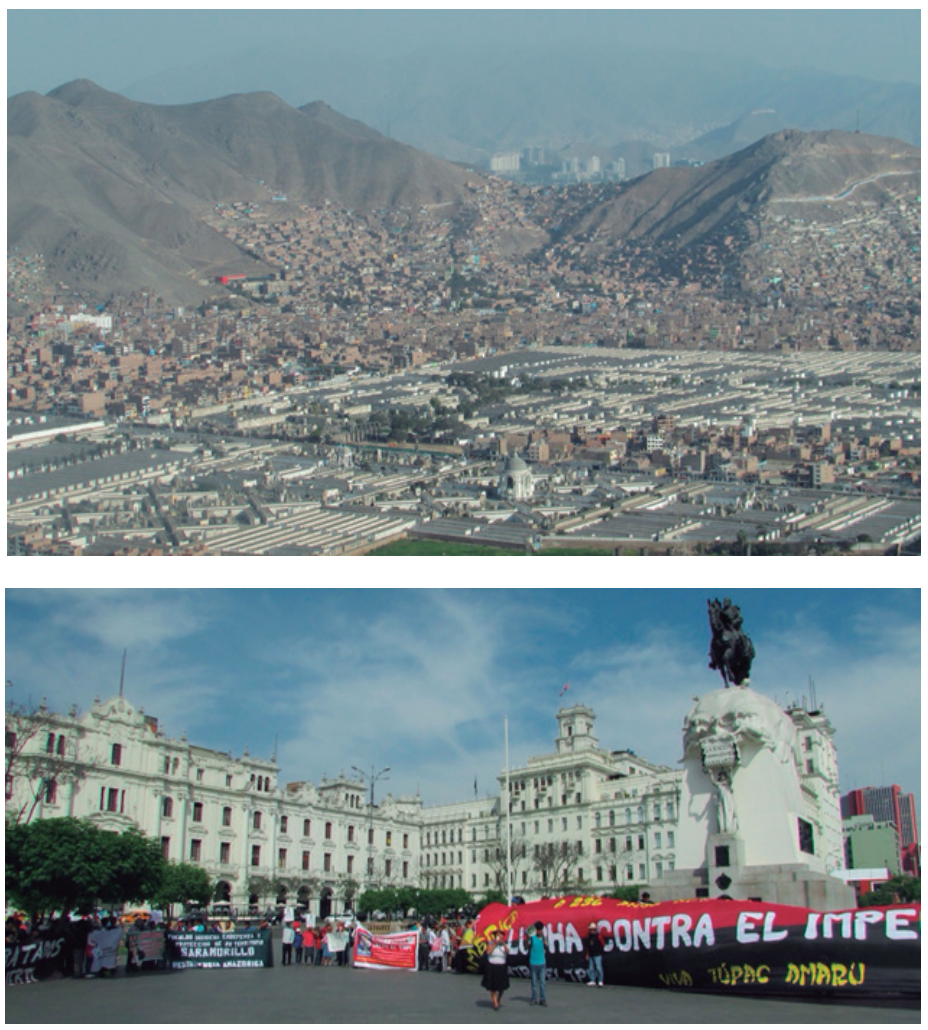

Figuras 6 y 7: Dispersión metropolitana y sujeto indígena en situación espacial duradera (movilizado a lo largo de siglos para seguir existiendo), en la Plaza San Martín Lima, Perú. Fuente: Acervo del autor, 2016.

trabajo, J. P. Sartre comenta que la emoción no es un accidente, sino una expresión (en aspectos definidos) de la totalidad sintética humana en su integridad; no es el efecto de la realidad humana, sino que se realiza en forma de emoción; es la forma organizada de la existencia humana (Sartre, 2010).

En esta propuesta existencialista, debe considerarse que el sujeto no es responsable sólo de su individualidad irrestricta, sino de todos los individuos (existimos al mismo tiempo que construimos nuestra imagen, que es válida para todos y para nuestro tiempo, para la humanidad, emocionalmente). "Para el existencialista, sólo hay realidad en la acción. El hombre no es más que su proyecto, existe sólo en la medida en que se realiza; por lo tanto, no es más que el conjunto de sus actos, nada más que su vida" (Sartre, 2002, p. 250).

Este método enseña que la acción de un grupo, por totalizante o total que sea, tiene una situación bien determinada por las elecciones de cada individuo (en el Estado, el gobierno, los partidos o incluso representantes de escuelas, vecindarios, comunidades, etc.) Por lo tanto, es importante comprender la crítica de Sartre al marxismo, su 
abstracción inherente, para aclarar lo que es posible a través del análisis, además de un radicalismo que niega el Estado y la planificación, que debe visualizar la corporeidad de los sujetos en lo cotidiano. Una prueba contundente de la violencia de la abstracción estatal son los apátridas, que viven en las periferias de las ciudades, adultos o niños nacidos en el contexto de migraciones forzadas por guerras o eventos trágicos que, sin documentos, pierden su referencia de identidad socioterritorial, origen cultural y nacionalidad, pasando por los más difíciles juicios existenciales, debido a la incapacidad del gobierno para reconocer al ciudadano en carne y hueso, humanamente.

La población es una abstracción si omito las clases que la constituyen; estas clases son palabras vacías de significado, si ignoro los elementos en los que se basan: trabajo asalariado, capital localizado [...]; y las categorías económicas están insuficientemente determinadas a menos que establezcamos que se aplican a la población inglesa, a hombres reales que viven y hacen historia en el país capitalista de industrialización avanzada. En esta lógica de totalización, Marx muestra la acción de las superestructuras sobre los hechos de infraestructura. (Sartre, 2002, p. 50)

Las estrategias de gestión metropolitana y los consorcios intermunicipales aparecen en el discurso como apuestas de reestructuración territorial para remediar los problemas redundantes de dispersión, concentración o desconcentración de las grandes ciudades. Se habla de una ecología política de la urbanización, la importancia de rescatar los movimientos sociales en las luchas urbanas y los conflictos socioambientales, así como la necesidad de políticas territoriales que garanticen la función social de la tierra ${ }^{17}$. Sin embargo, la política u oportunidades espaciales apenas son operativas cuando los sujetos reales de la vida cotidiana, con su imaginación, juegan un papel decisivo sobre su destino. En Lo imaginario, Sartre es categórico: "La imaginación convertida en una función psicológica y empírica es la condición necesaria para la libertad del hombre empírico en medio del mundo", donde "toda conciencia es conciencia de algo", de modo que la imaginación es "el sentimiento implícito de lo real" (Sartre, 1996, pp. 243-244).

La principal demanda de una democracia visual e imagética urbana, que sea descentralizada, está en el cuidado de considerar que cualquier representación técnica de la ciudad como un todo conlleva el riesgo de perdida de lo cotidiano singular o de los dichos sujetos reales (cf. Sennett, 1998; Costa, 2011). Por eso, el imaginario y la cultura tienen un papel crucial en el lineamiento de la planificación y cambio de la realidad social, pues exijen del investigador un aterrizaje territorial de análisis simultáneo: desde “arriba” (figuras 6) y desde “abajo” (figuras 7). El caso del centro 

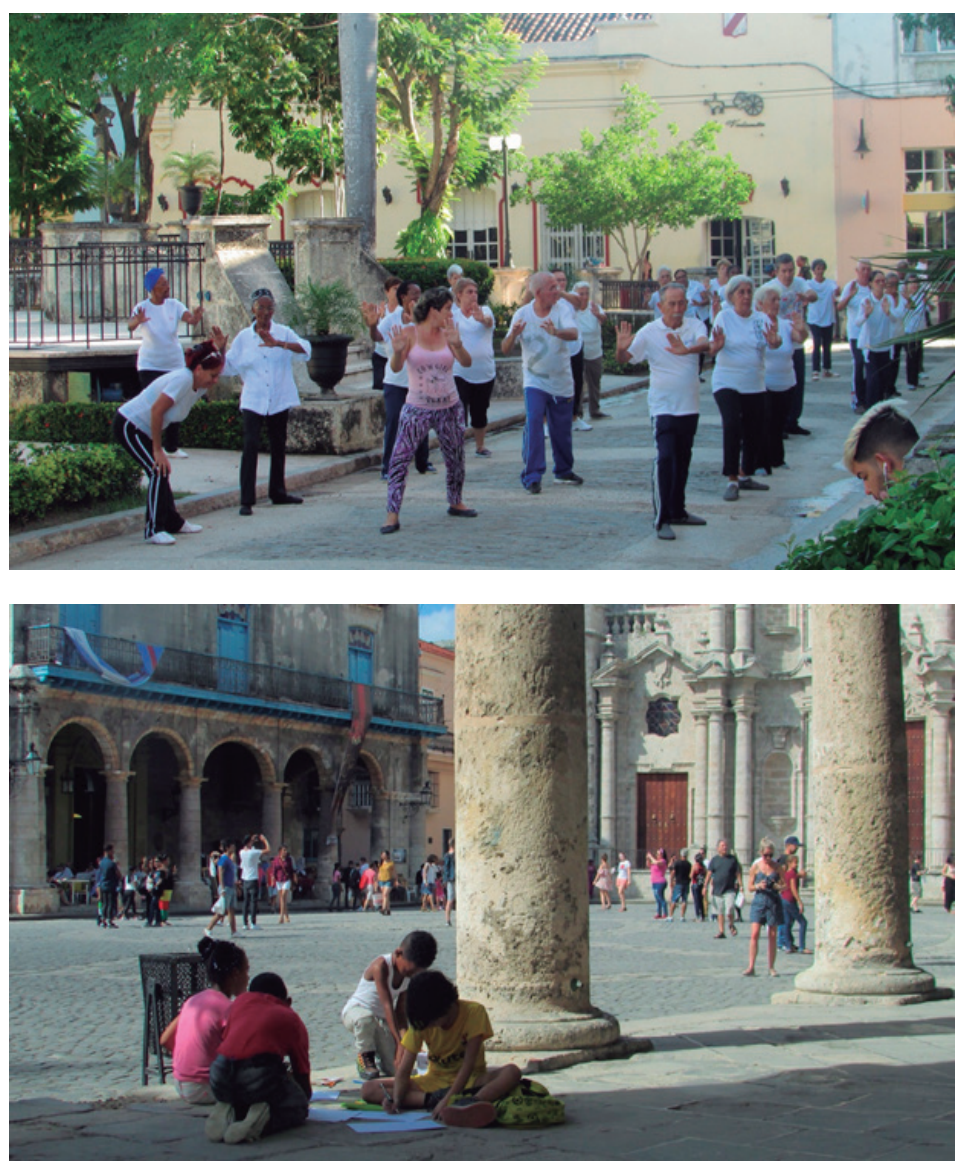

Figuras 8 y 9: Activación popular del espacio público por adultos mayores en Camaguey (Plaza Ignacio Agramonte) y niños en Habana (casco antiguo).

Fuente: Acervo del autor, 2018.

histórico de Lima, Peru, es emblemático de los problemas de la planificación urbana y la relevancia de los movimientos sociales en Latinoamérica. El sitio presenta, de entre otras, dos espacialidades importantes conectadas por la calle Jirón Junin, que son la Plaza de Armas y la Plaza San Martín, palcos de grandes protestas, huelgas y expresión popular, activando vivamente el espacio público ${ }^{18}$ (figura 7); este eje tiene intenso flujo de personas, que lo cruzan diariamente, del barrio Rímac hacia el

18. Nuestra concepción de espacio público dialoga con Cefaï \& Joseph (2002), para quien la idea de público conlleva el colectivo formado por todos aquellos que pueden ser afectados por consecuencias de acciones externas, esperadas o inesperadas, de interés compartido y regulado a través de acción propia; un organismo que siente y resiente, piensa y juzga, sin ser localizable en un cuerpo, sino distribuido en actividades situadas (con un sistema de lugares articulado por cuadros de referencia de la vida publica). El espacio publico es revelado o activado cuando la sociedad entra en operación por demandas articuladas, en nombre del público. 
otro lado del centro; la zona es muy dinámica por el comercio mayorista, minorista e informal. Además, el centro histórico de Lima conserva el uso residencial, con casonas ocupadas, desde mediados del siglo $\mathrm{xx}$, por imigrantes de las províncias o de la Sierra, que reemplazaron a la élite radicada ahí durante siglos y que migró a nuevos barrios al sur de la metropolis. Temas como la dificultad de los habitantes (de menores recursos) para dar mantenimiento a los inmuebles que ocupan, el intenso tráfico catalizado por el comércio de importancia nacional y las delincuencias y violencias reales e imaginadas (caso del estigma espacial sobre el centro, "reconocido" como "peligroso" para la circulación nocturna) pueden ser enfrentados con el estudio y cambio del imaginario popular sobre este territorio, considerándolo en las tomas de decisiones, pues este sector de ciudad es la prueba empírica del sujeto conciente de su papel en la activación popular del espacio público en las ciudades de América Latina (Costa, 2018) ${ }^{19}$; tema urgente, pues el espacio público es el locus máximo de la imaginación, representación, expresión y transgresión popular, por las demanandas del sujeto migrante o urbano.

Objetivación del trabajo (y sus contenidos) y de las relaciones sociales concretizan la historia. La crítica de Sartre esta direccionada al marxismo abstracto incapaz de totalizaciones. El marxismo predica la aproximación de la economía y la negación del carácter ideológico abstracto, así como la crítica del desarrollo económico. El existencialismo sartreano se niega a abandonar la vida real o las posibilidades inherentes al nacimiento, para contemplar una universalidad que simplemente se refleja indefinidamente. "Sin ser infieles a las tesis marxistas, pretendemos encontrar las mediaciones que permitan engendrar lo concreto singular, la vida, la lucha real y fechada, la persona, a partir de las contradicciones generales de las fuerzas productivas y las relaciones de producción" (Sartre, 2002, p. 55). La biografía del individuo, desde la infancia, revela las luchas de clases, el momento de las relaciones de producción o, en el sesgo de lo geográfico y lo sociológico urbanos, los significados más genuinos de la ubicación, de la producción del espacio y sus efectos en su propio cuerpo afectado en lo cotidiano.

El sujeto urbano es el que mejor puede definir sus necesidades y dirigir su proyecto propio (anclado a planes urbanos técnico-humanistas), agudizado por el imaginario, producto y productor de la razón instrumental y la propia experiencia. Sin embargo, Castoriadis (1982, p. 191) advierte sobre los sujetos del mundo burocrático, que ignora la totalidad y su relación con el mundo; estos indivíduos que son...

19. Informaciones de trabajo de campo realizado por el autor, en Lima (y Cuzco), el octubre y noviembre de 2016. 

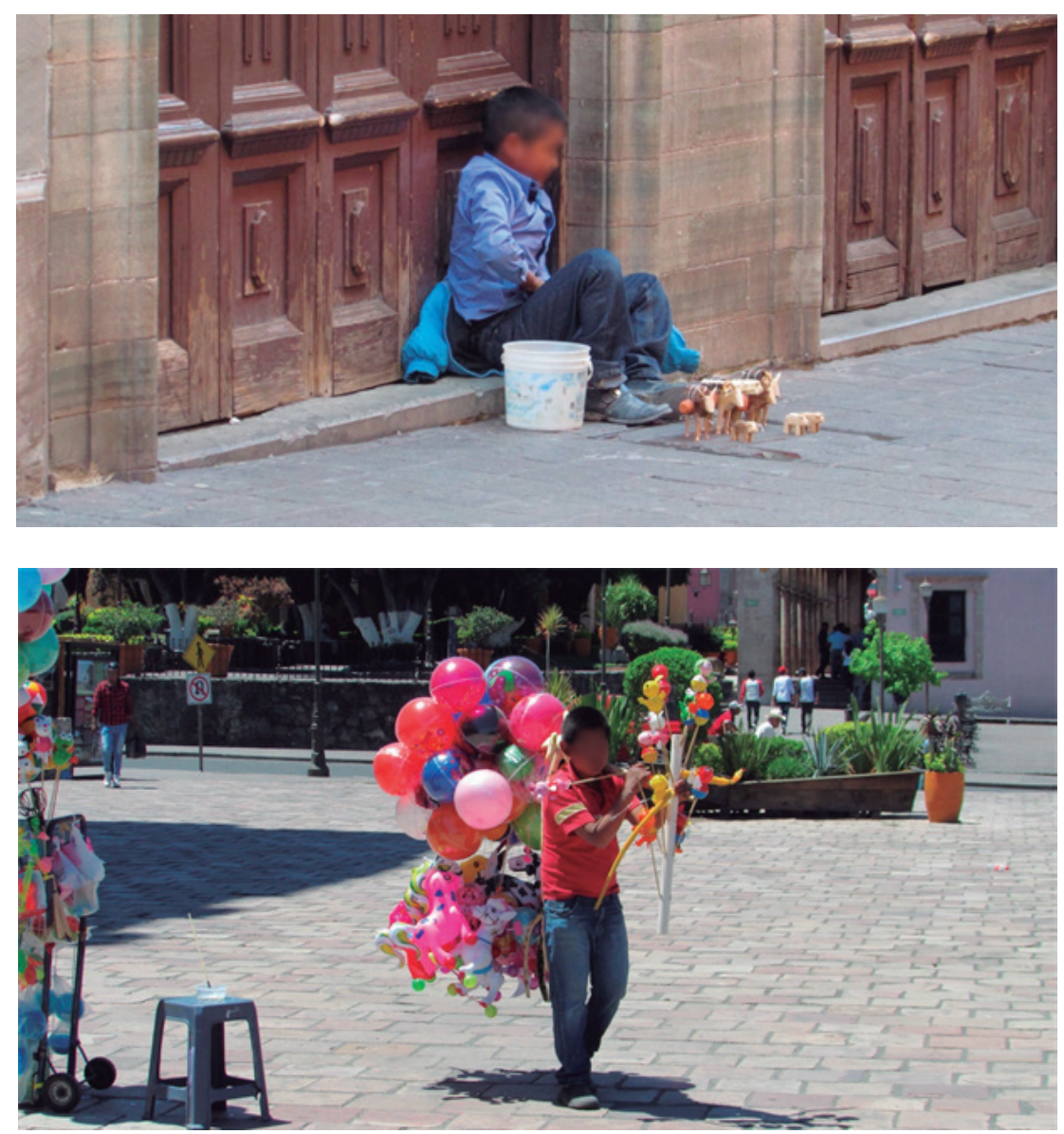

Figuras 10 y 11. Trabajo infantil en el turismo. Guanajuato y Yuriria, México.

Fuente: Acervo del autor, 2018 y 2019.

[...] puntos nodales simples en el entrelazado de mensajes, solo existen y son válidos según el Estado y las posiciones que ocupan en la escala jerárquica. Lo que es esencial en el mundo es su reducibilidad a un sistema de reglas formales, incluidas las que le permiten calcular su futuro. La realidad existe solo en la medida en que está registrada, en el límite, lo verdadero no es nada y solo el documento es verdadero. Y aquí viene lo que nos parece ser la característica específica y más profunda de la imaginación moderna, la que también está llena de consecuencias y promesas. Este imaginario no tiene carne propia, toma su materia de otra cosa, es una fantástica inversión, valorización y autonomización de elementos que en sí mismos no dependen del imaginario: lo racional limitador de la comprensión y lo simbólico.

Los planes maestros y la zonificación urbana tratan con la población general o la sociedad urbana de manera genérica y abstracta. El urbanismo reconoce, discursivamente, para la elaboración de un plan, la consulta con todos los organismos y enti- 
dades públicas sectoriales, en todos los niveles de la federación, así como la apertura a la participación ciudadana ${ }^{20}$. Además del plan maestro, se elaboran otros planes urbanos (proyecto de parcelación de tierras, proyecto de regularización de tierras, plan de operación urbana consorciada), verticalmente y con una visión tecnicista de lo empírico, abogando por grandes porciones de espacio, olvidando las singularidades de la vida cotidiana, que sólo la investigación participante puede revelar. En el lapso producido por el desarrollo capitalista (tiempo de la rutina, repetición y de lo cotidiano), que las contradicciones hacen saltar fuera el momento de la creación y anuncio de la História -el tiempo del posible; anuncio que indica al indivíduo común, en la vida cotidiana, que es en la práctica que se instalan las condiciones de transformación del imposible en posible (Martins, 1998; Lefebvre, 1968).

Todo eso fundamenta pensar una planificación urbana posible agregando el imaginario individual y colectivo formados desde lo cotidiano fraccionado. Los espacios públicos pueden constituir locus de reunión comunitaria integrada (o rebelión), especialmente cuando la ciudad se está fragmentando (cf. Sennett, 1998). Un caso notable y muy exitoso en Latinoamérica es el de Cuba, en especial la ciudad Camagüey, al sur de la isla. Creatividad, solidaridad y empatía señalan la formación psico-social singular del cubano reflejada en sus prácticas y en los espacios públicos. La horizontalidad de las interacciones sociales fomentadas por la administracción estatal se verifican en la organización de las bodegas, farmacias populares, clínicas populares, talleres populares, tiendas populares, mercados populares, apropiación popular del espacio público (figuras 8 y 9) y, principalmente, el uso público y colectivo de los edificios, donde el Estado detiene la "propiedad" de los inmuebles y posibilita que cada familia del país viva o tenga residencia por toda la vida. Escuelas y centros de salud también ocupan tales edificios, para el bien colectivo. El modo de producción socialista, en Cuba, remarca una dimensión de planificación territorial en que lazos de interconocimiento y de entreayuda son reales. Este caso muestra que la utopía necesaria planteada por Cefaï (2011, p. 153) [con una mirada operada desde el "Norte"] se alimenta de hechos concretos existentes en el "Sur", o sea, en Cuba se ha realizado un giro sobre el "sentido de la propiedad privada, la conciencia de clase y el amor por la nación” idealizados por el autor. En Cuba (Habana y Camagüey, por ejemplo), el espacio público es el locus efectivo de manifestaciones, fiestas, conciertos, encuentros de niños, jóvenes y ancianos, para el ocio recreativo o actos políticos; da cuerpo a cualquier movimiento político, celebrando el activismo en lo cotidiano, a escalas espacio-temporales ampliadas, como sugiere D. Cefai ${ }^{21}$.

20. Vea la discusión detallada en Pinto (2013).

21. Información de trabajo de campo realizado por el autor, en Cuba, en abril de 2017 y noviembre de 2018. 
Según J.P. Sartre, no es la tenencia de la tierra o la naturaleza estrictamente intelectual de su trabajo lo que hace que un individuo sea burgués. Él es parte de la burguesía porque nació en ella o fue formado en ella. En el existencialismo, la particularidad de la historia personal frente al mundo es válida a través de las contradicciones de la propia vida familiar, en un grupo, en una comunidad, en el país. "El niño se convierte en esto o aquello porque él o ella vive lo universal como particular: ¿qué conflictos religiosos, de aprendizaje y familiares viven?" (Sartre, 2002, p. 57). El individuo en su todo está en el adulto que vive en la ciudad, en el campo y en el vecindario; no sólo sus determinaciones actuales, sino que el peso de su historia es lo que le da sentido. Cabe destacarse que para Sartre, el psicoanálisis no se opone al materialismo histórico o al existencialismo. Esta dimensión del método construye otra representación y praxis sobre el sujeto y su imaginario urbano, en lo que concierne al conocimiento socioespacial transtemporal mismo, lo que afecta su cuerpo y su mente en las ciudades.

Para Sennett (1998), cuanto más los barrios son guetos de identidad de clase o raza, más incierto será el futuro de la ciudad, pues el "aislamiento" social genera conflictos violentos e indiferencia al destino del otro. Por eso, hay que pensar acciones políticas móviles donde el pueblo sea protagónico, desde sus propios sitios o desde otros, para que sean reconocidos y visibles por toda la gente, conectados con toda la ciudad. A estas estrategias socioespaciales Costa (2018) les denomina conexiones territoriales afectivas; Sennett (1998) las define como acciones que comparten terrenos mentales comunes al actuar localmente.

El sociólogo mexicano Solís Quiroga consideraba, en 1964, que el impacto de la conquista provocó la aparición de múltiples casos de miseria, vagancia, embriaguez, vicio y abandono de la infancia, drama que ahora enfrenta su país y que se inició por la pérdida de la organización indígena y de la propiedad de la tierra, esclavitud, abandono forzoso de los hijos por sus padres esclavos, la falta de preparación de todos, el hambre y la imposibilidad de reorganizar la familia. El caso de los niños (y mayores) en las calles de México (figuras 10 y 11) es una violencia referente a la mencionada "indiferencia al destino del otro", que se identifica en toda América Latina. "Éste es el panorama que encontramos en la historia de México independiente, que padeció grandes pobrezas, aunque haya abolido la esclavitud. Nuestra familia y nuestra sociedad, aun queriendo reorganizarse, no han vuelto a adquirir la reciedumbre ni la solidez antigua para ejercer su papel protector e integrador del niño a la sociedad de que forma parte" (Solís Quiroga, 1964, p. 791). Más de medio siglo después de las consideraciones de Solís Quiroga, las violencias y el trabajo infantil (catalizado también por la forma de desarrollo turístico mexicano ${ }^{22}$ sigue siendo problemas 
que deben ser enfrentados por expertos y planeadores cuya ideología incorpore modalidades e intensidades de compromiso capaces de valorar distintos actores y su imaginario, y no se restrinjan a modelos de gestión territorial de espectro estructural, racional o estratégico (cf. Cefaï, 2011; Costa \& Peluso, 2016) ${ }^{23}$.

Los argumentos presentados establecen el significado histórico de la vida y el lugar del sujeto situado para una planificación urbana posible. Historia oral y de vida, entrevistas, mapas mentales, hablados y colaborativos, observación participativa, etnografía, estudio del medio, grupos de discusión etc., podrían ser asumidos como un procedimiento metodológico (de entre los consagrados) en la elaboración de planes maestros y de la zonificación urbana, a fin de humanizar las técnicas y a los técnicos, incluyendo en el trabajo de los expertos valores simbólicos, afectivos y, con exactitud, las vulnerabilidades sociales imaginadas y espacializadas. Gorelik (2002), de manera crítica radical, considera tales representaciones como metáforas cartográficas de la realidad, que fluctuan entre dos polos o textos base: La invención de lo cotidiano (Michel de Certeau, 1980) y El posmodernismo como lógica cultural del capitalismo tardio (Fredric Jameson, 1984). Para Gorelik (2002, pp. 5-6),

[...] los estudios culturales urbanos latinoamericanos se han estado moviendo, con tanta libertad como imprecisión, dentro del vasto arco que se tensa entre los dos polos mencionados. Podrían tratar de encontrarse [...] ciertas matrices, ya disciplinares, ya ideológicas, con mayor tendencia a uno u otro polo: es fácil notar una atracción mayor hacia el polo antimoderno de los estudios que provienen de la antropología en sus versiones populistas, y hacia el postmoderno, de la geografía o la sociología en sus versiones neomarxistas o neoestructuralistas. Pero son sólo las tendencias de base, ya que lo que predomina en la superficie como característica definitoria de los estudios culturales urbanos es un collage teórico en el que se alinean sin conflicto los autores más diversos a través de una lógica del desplazamiento metafórico (de un nombre al otro, de una categoría a la otra) que le debe más a la asociación libre que a un procedimiento argumentativo.

Más allá de Gorelik (relativizada su importante crítica radical a las confusiones epistemológicas de algunos estudios culturales urbanos en Latinoamérica), este trabajo defiende que el pensamiento y la ejecución de la planificación deben integrar las nociones de existencia y cultura, es decir, el indivíduo completo (desde la

23. Trabajos de campo realizados en ciudades mexicanas del centro (México, Puebla, Celaya, Guanajuato, Zacatecas, Morelia, Tlaxcala, San Miguel Allende y otras), del sur (Mérida, Cozumel, Izamal, Oaxaca, Valladolid), del medio-norte (San Luís Potosí y Real de Catorce) y del oeste (Guadalajara) posibilitaran identificar el problema del trabajo informal de niños y mayores en las calles del país, tema y problema observados también en ciudades de Brasil, Nicaragua, Costa Rica y Panamá, entre 2016 y 2020. 
infancia hasta la vejez) con su historia inherente al lugar, su ancestralidad vivida, que perdura porque es, sobre todo, imaginada. La preservación del medio ambiente y la valorización cultural sólo tienen una ubicación: la del sujeto de la vida cotidiana, ya que los valores son atribuidos y consagrados por él, con su imaginación ante la racionalidad del mundo y sus efectos materiales, emocionales y físicos.

Queda por añadir que la cultura es un complejo de valores morales, intelectuales, materiales y estéticos que dan sentido a una sociedad como el objetivo de la organización, división y dirección de su trabajo, el bien que debe lograrse a través del modo de vida instituido (Marcuse, 1998, p. 153). El aumento de la libertad individual, colectiva y pública, la disminución de las desigualdades (inhibidoras del desarrollo de los individuos y su personalidad), así como la gestión capaz y racional son valores culturales también presentes en la sociedad industrial avanzada, dice H. Marcuse. Debe agregarse a esta definición de cultura que "todo el conjunto de la realidad se da principalmente participando de la conciencia, o más bien como conciencia" (Sartre, 2011, p. 42). Esto permite decir que la conciencia que promueve la razón instrumental produce la razón de la vida popular segregada, en un estímulo recíproco que presenta la cultura como un complejo de valores moral-estéticos distintos, pero formulados en lo cotidiano justo por la predicción dialéctica del imaginario.

En este sentido, la cultura es más que una ideología, es el proceso de humanización caracterizado por el esfuerzo colectivo (con resultados desequilibrados) para conservar la vida, pacificar la lucha por la existencia o mantenerla dentro de límites controlables, para consolidar la organización productiva de la sociedad, desarrollar las capacidades intelectuales de los sujetos, disminuir y sublimar la agresión, la violencia, la miseria y las enfermedades urbanas ${ }^{24}$.

La cultura está suspendida (incluso prohibida) donde el camino de la inhumanidad está pavimentado; está desacreditada (incluso negada) donde se construye el mayor contenedor de resistencia colectiva: en las periferias urbano-rurales de la ausencia-presencia del Estado-mercado; ubicaciones reproductivas de formas de vida espacial muy singulares ${ }^{25}$, que se pueden recuperar con creatividad y retomándolas de las utopías que gravitan entre lo cotidiano y el imaginario ciudadano. Hay que entender, con Certeau (1995, p. 233), que la cultura es flexible y el análisis se mueve en todas direcciones sobre las inseguridades que proliferan en los intersticios del cálculo, visto que ella no está involucrada a la engañosa estadística de los signos objetivos. "Así, las formas de utilizar el espacio huyen a la planificación urbanísti-

24. Marcuse (1998) ahonda en esta discusión.

25. Véase en Costa $(2016,2017,2018,2021$ [aceptado]) el debate que privilegia el patrimonio-territorial en territorios de excepción como resistencia cultural en las periferias de las ciudades en América Latina. 
ca: capaz de crear una composición de lugares, de espacios ocupados y vacíos, que permiten o impiden la circulación”; se debe articular esa racionalidad en concreto con los sistemas culturales, múltiplos y fluidos; organizar la ocupación efectiva de los espacios internos (viviendas) y externos (calles, plazas), no los debilitando con innumerables vías o aniquilando la posibilidad de activación del espacio público.

La cultura, en este debate de los hechos socioespaciales, emerge de la ontología imaginaria del sujeto, explicando acciones de opresión o resistencia transescalar, de la comunidad a la nación sujeta al yugo económico o neocolonial, que tiene la ciudad y el territorio como sus principales depositarios. En resumen: la cultura urbana y lo imaginario pueden verse con un nuevo fin: atribuir un significado concreto al sujeto, en su plena existencia en el mundo nuevo y con la valoración de su lugar, reconociendo tanto la fuerza de las racionalidades como de las emociones (cf. Santos, 2002).

Finalmente, es importante señalar la consideración de Marcuse (1998), al decir que nuestra situación cultural (universo de comportamiento social racional) rechaza y desvalora las ciencias humanas calificándolas como ciencias no-cientificas, por tratar principalmente de valores personales, emocionales, metafísicos, poéticos, ideologizados, que sólo se tornan científicos cuando son traducidos a términos operacionales. Pero, la propuesta de este trabajo no es entregar las verdades de las ciencias humanas a las normas que gobiernan a la sociedad establecida productivamente, sino confrontarlas potencializando el sujeto periferizado (a través de su imaginación), en la construcción interna de la ciudad democrática; para eso, no es necesaro negar radicalmente los proyectos urbanísticos o las técnicas, sino criticarlos proponiendo humanizarlos. Hay que recordar con Sennett (1998) que la democracia descentralizada tiene una afinidad particular con la ciudad moderna, que no son asentamientos humanos coherentes y si una "reunión de diferencias": familias, intereses económicos y miradas políticas. Las ciudades, en todas sus escalas, son asentamientos cada vez mas amplios, pero integrados y unificados por diferencias que deben ser comprendidas desde la conciencia y las necesidades conformadoras de la esencia popular.

La geografía, la sociología y la antropología, al evidenciar las demandas en el imaginario social, con sus formas de operación metodológica, tienen mucho para colaborar en una praxis urbanística eminentemente popular.

La geografía social imaginativa del lugar en la planificación de la ciudad.

Palabras finales

La popularización de las mercancías ha significado la popularización de las culturas cambiadas en mercancías. Sin el objetivo de lo bello, sin el atributo de belleza y estética agradable a las masas, no habría necesidad cultural. Esta necesidad es la 
variable indiscutible de la reproducción de la vida urbana, concreta, imaginaria y espiritualmente. Las ciencias sociales no pueden descuidar el contenido político y adaptado de este imaginario, las variadas formas de lenguajes y narrativas, cuando la necesidad no es desinteresada o abstracta, sino que corresponde a estrategias con un punto de vista localizado: la reproducción expandida de las necesidades alcanza lo superfluo y niega lo primario, conscientemente. Por lo tanto, la planificación urbana deliberada para minimizar el ideal de estas necesidades y la violencia de las técnicas, de la racionalidad ciega a la totalidad concreta, debe incluir la conciencia del sujeto subalternizado en las ciudades, reimaginando y reincorporando su localización geocultural. Así operará una geografía social imaginativa del lugar, a través de interacciones materiales, sentimientos individuales e imaginarios colectivos denunciantes de vulnerabilidades, para vincularlas con la planificación.

Al mismo tiempo que las ciudades favorecen el imaginario globalizado de las innovaciones, albergan poblaciones que conservan sus propios hábitos residenciales, comerciales, alimentarios, simbólicos y espirituales, por la fuerza de su imaginario: maneras de habitar por formas y contenidos ancestrales y vernáculos; festivales sagrados y profanos de origen rural, con componentes negros, indígenas y extranjeros; religiones que se han enfrentado a la imposición hegemónica de creencias católicas o protestantes; formas de comer que abarcan siglos y se reproducen en las grandes ciudades, los platos más caros y los barrios menos favorecidos, el arte globalizado que es incapaz de extinguir el arte popular de las nuevas centralidades periferizadas. Estos y otros ejemplos muestran resistencia al impulso de las necesidades urbanas hegemónicas, que la crítica no puede olvidar; significan la reproducción cultural de la vida urbana total, acciones rituales de duración y metamorfosis, creatividad de la existencia popular frente a la urbanización.

Para que la vida urbana digna se consolide en la ciudad democrática, es necesario repensar la planificación, cuya naturaleza sobrevalora los negocios inmobiliarios, financieros, mediáticos, técnicos y de consumo como ideologías del progreso. Es importante reformular las relaciones de la politica cultural con la esfera pública y con la ciudadania, por medio de una planificación urbana posible, en la que el sujeto existente e imaginativo de su papel en la transformación espacial tome decisiones. La creatividad, las potencialidades y las vulnerabilidades de los sujetos localizados deben ser asimiladas y operadas, con su presencia en el lugar de existencia y en el plan estratégico.

Las posibilidades (para algunos, nulas, porque la planificación sería un mero instrumento de control estatal) derivadas de una lectura existencial y cultural del territorio convergen en un elemento importante: la producción de un indicador sintético de análisis geográfico y sociológico aplicado a la planificación, que es la 
calidad de vida urbana medida por la existencia y la emoción. La planificación y, por así decirlo, los planes maestros y la zonificación, deben elaborar indicadores complejos representados en mapas lógicos y mentales, en los cuales el sujeto sea el partícipe de la espacialización y uno de los conductores políticos de la técnica. Índices de pobreza, desarrollo, segregación social, enfermedades, distribución del ingreso, vulnerabilidad social, servicios públicos, calidad del agua, calidad ambiental, confort térmico, circulación y elementos de movilidad urbana, accesibilidades, patrimonio, empleo, áreas de ocio y turismo, estigmas, violencia doméstica etc. son productos de lo imaginario (por su función predictiva) y, por lo tanto, interpretados y susceptibles de ser remediados imaginaria y concretamente ${ }^{26}$.

J. de Souza Martins considera que es en el instante de las rupturas del cotidiano, en los instantes de la inviabilidad de la reproducción, que se instaura el momento de la invención, de la osadía, del atrevimiento, de la transgresión; es donde la desordenen es otra, como es otra la creación. Significa valorar, en la planificación, el mundo de la vida, ponerlo en su lugar, romper con el silencio y la letárgia del sujeto ubicado, enalteciendo, simultáneamente, lo cotidiano.

26. Costa (2011 \& 2011a) y Costa y Scarlato (2019) también presentan metodología en este sentido. 


\section{Referencias}

Adorno, Theodor. (2009), Dialética negativa. Rio de Janeiro, Zahar.

Alvarado, Ilia \& Costa, Everaldo. (2019), "Situación geográfica turística en la era urbana y devenir campo-ciudad en América Latina”. Investigaciones Geográficas, México, 99 (2): 1-24, julho. Disponible en http://dx.doi.org/10.14350/rig.59792.

Alvarado, Ilia \& López, Álvaro. (2018), Turismo, patrimonio y representaciones espaciales. Tenerife, Colección Pasos, n. 22.

Baudrillard, Jean. (1991), Simulacros e simulação. São Paulo, Relógio D’Água.

Bauman, Zygmunt. (2013), A cultura no mundo líquido moderno. Rio de Janeiro, Zahar.

Bauman, Zygmunt \& Donskis, Leonidas. (2014), Cegueira moral. Rio de Janeiro, Zahar.

Beck, Ulrich. (2010), Sociedade de risco: rumo a outra modernidade. São Paulo, Editora 34.

Campos Filho, Candido. (1989), Cidades brasileiras: seu controle ou o caos. São Paulo, Nobel.

Canclini, Néstor. (2003), A globalização imaginada. São Paulo, Iluminuras.

Castoriadis, Cornelius. (1982), A instituição imaginária da sociedade. Rio de Janeiro, Paz e Terra.

Cefaï, Daniel. (2009), “Como nos mobilizamos? Sociologia da ação coletiva”. Dilemas, 4 (2):

11-48. Disponible en https://revistas.ufrj.br/index.php/dilemas/article/view/7163.

CEFAÏ, Daniel. (2011), “Diez propuestas para el estudio de las movilizaciones colectivas”. Revista de Sociologia, 26 (1): 137-166. DoI: 10.5354/0719-529X.2011.27491.

CEFAÏ, Daniel \& JOSEPH, Isaac. (2002), L'heritage du pragmatisme, conflits d'urbanite et epreuves de civisme. La Tour d'Aigues, Editions de l'Aube, 2002.

Certeau, Michel de. (1995), A cultura no plural. Campinas, Papirus.

Costa, Everaldo. (julio 2017), "Ativação popular do patrimônio-territorial na América Latina: teoria e metodologia”. Cuadernos de Geografía, Colombia, 26 (2): 53-75. Disponible en https://revistas.unal.edu.co/index.php/rcg/article/view/59225/pdf.

Costa, Everaldo. (2011a), "Geografia urbana aplicada: possibilidades, utopias e metodologias”. XII Simpósio Nacional de Geografia Urbana. Belo Horizonte, UfMG, pp. 1-16. https:// repositorio.unb.br/handle/10482/9601.

Costa, Everaldo. (julio 2018), “Riesgos y potenciales de preservación patrimonial en América Latina y el Caribe”. Investigaciones Geográficas, México, 96 (2): 2-26. http://dx.doi. org/10.14350/rig.59593.

Costa, Everaldo. (marzo 2021, aceptado), “Patrimonio-territorial y territorio de excepción en América Latina, conceptos decoloniales y praxis". Revista Geográfica Venezolana, 62 (1): 01-32. http://www.saber.ula.ve/regeoven/.

Costa, Everaldo. (2011), Totalidade urbana e totalidade-mundo: as cidades coloniais barrocas face à patrimonialização global. São Paulo. São Paulo, tese de doutorado, Faculdade de Filosofia, Letras e Ciências Humanas da Universidade de São Paulo, FfLCH-Usp. Disponible en https://teses.usp.br/teses/disponiveis/8/8136/tde-14032011-104656/pt-br.php. 
Costa, Everaldo. (2016), "Utopismos patrimoniais pela América Latina: resistências à colonialidade do poder”. Actas XIV Coloquio Internacional de Geocrítica. UB, Barcelona, pp. 1-32. Disponible en http://www.ub.edu/geocrit/xiv_everaldocosta.pdf.

Costa, Everaldo \& Alvarado, Ilia. (octubre 2019), "Heterotopía patrimonial: concepto para estúdios latinoamericanos". Scripta Nova, Barcelona, 620 (23): 1-28

Costa, Everaldo \& Peluso, Marília. (maio 2016), "Imaginário urbano e situação territorial vulnerável na Capital do Brasil”. Biblio 3W, Barcelona, 23 (2): 01-29. http://www.ub.edu/ geocrit/b3w-1151.pdf.

Costa, Everaldo \& SCarlato, Francisco. (deciembre 2019), “Geografía, método y singularidades revisadas en lo empírico”. GeoUSP, 23 (3): 1-28. http://www.revistas.usp.br/geousp/ article/view/161552.

Costa, Everaldo \& STEInke, Valdir. (maio 2014), "Brasília meta-síntese do poder no controle e articulação do território nacional”. Scripta Nova, Barcelona, 493 (44): 01-32. Disponible en http://www.ub.edu/geocrit//sn/sn-493/493-44.pdf.

Freitag-Rouanet, Bárbara. (dez. 2000), “A cidade brasileira como espaço cultural”. Tempo Social, São Paulo, 12 (1): 29-46, https://doi.org/10.1590/S0103-20702000000100003.

Gorelik, Adrián. (febrero 2002), "Imaginarios urbanos e imaginación urbana. Recorrido por los lugares comunes de los estudios culturales urbanos". Eure, 28 (83): 1-9. http://dx.doi. org/10.4067/S0250-71612002008300008.

Gorelik, Adrián. (enero 2005), “A produção da cidade latinoamericana”. Tempo Social, 17 (1): 111-133. https://doi.org/10.1590/S0103-20702005000100005.

Habermas, Juergen. (1968), Técnica e ciência como ideologia. Lisboa, Edições 70.

Hiernaux, Daniel. (mayo 2007), “Los imaginários urbanos: de la teoria y los aterrizajes en los estúdios urbanos”. Eure, Chile, 99 (3): 17-30. http://dx.doi.org/10.4067/S025071612007000200003.

Lefebvre, Henri. (2010), Hegel, Marx, Nietzsche o el reino de las sombras. Madri, Siglo XXI.

Lefebvre, Henri. (1968), La vie quotidienne dans le mond moderne. Paris, Idees - Gallimard.

Magnani, José. (dez. 2005), “Os circuitos dos jovens urbanos”. Tempo Social, São Paulo, 17 (2): 173-205. Disponible en https://doi.org/10.1590/S0103-20702005000200008.

Matos, Olgária. (2010), “Modernidade: o deslimite da razão e o esgotamento ético”. In: Novaes, Adauto. (org.). Mutações: A experiência do pensamento. São Paulo, Sesc, pp. 157-176. Marcuse, Herbert. (1998), Cultura e sociedade. Rio de Janeiro, Paz e Terra.

Martins, José. (jan. 1998), “O senso comum e a vida cotidiana”. Tempo Social, São Paulo, 10 (1), 1-8. Disponible en https://doi.org/10.1590/ts.v10i1.86696.

Merleau-Ponty, Maurice. (2006), Fenomenologia da percep̧̧ão. São Paulo, Martins Fontes. Moura, Cristina \& Januzzı, Vinicius. (ago. 2019), "Brasília classificada: novos espaços de classe média na capital federal”. Tempo Social, São Paulo, 31 (1): 113-134. Disponible en https://doi.org/10.11606/0103-2070.ts.2019.151261. 
Moura Costa, Heloisa. (2013), “A metrópole brasileira contemporânea e o planejamento territorial”. In: Gonzalez, S; Francesconi, J; Paviani, A. (orgs.). Planejamento e urbanismo no Brasil. Rio de Janeiro, Livre Expressão, pp. 65-82.

Noel Lapoujade, María. (2011), Filosofía de la imaginación. México, Siglo xxi.

Pinto, Vitor. (2013), “O princípio da tipicidade dos planos urbanísticos e a institucionalização do urbanismo no Brasil”. In: Gonzalez, S.; Francesconi, J. \& Paviani, A. (orgs.). Planejamento e urbanismo no Brasil. Rio de Janeiro, Livre Expressão, pp. 65-82.

Santos, Milton. (2002), A natureza do espaço. São Paulo, Edusp.

SAntos, Milton. (2008a), Manual de geografia urbana. São Paulo, Edusp.

Santos, Milton. (2007), O espaço do cidadão. São Paulo, Edusp.

Santos, Milton. (2009), Por uma outra globalização. São Paulo, Edusp.

Santos, Milton. (2008b), Técnica, espaço, tempo. São Paulo, Edusp.

Sartre, Jean-Paul. (2011), A imaginação. Porto Alegre, L\&pm.

SARTRE, Jean-Paul. (2002), Crítica da razão dialética. Rio de Janeiro, DP\&A.

SARtre, Jean-Paul. (2010), Esboço para uma teoria das emoções. Porto Alegre, L\&pm.

SARTre, Jean-Paul. (1996), O imaginário: psicologia fenomenológica. São Paulo, Ática.

Sartre, Jean-Paul. (2015), O que é a subjetividade? Rio de Janeiro, Nova Fronteira.

Sennett, Richard. (1998), The spaces of democracy. Michigan, Raoul Wallenberg Lectures.

Silva, Armando. (2014), Imaginários, estranhamentos urbanos. São Paulo, Sesc.

Solís Quiroga, Héctor. (enero 1964), "El problema de los niños que trabajan, vagan o mendigan en la vía pública”. Revista Mexicana de Sociología, 26 (3): 791-799. Disponible en http://revistamexicanadesociologia.unam.mx/index.php/rms/article/view/58872/52063.

VILlaÇA, Flavio. (2002), “Contribuição à história do planejamento urbano no Brasil”. In: DeÁk, C. \& SChiffer, S. (orgs.). O processo de urbanização no Brasil. São Paulo, Edusp, pp. 169-244.

\section{Resumo}

Planejamento urbano possivel, imaginário, existência e cultura

O planejamento urbano, do ponto de vista economicista e mecanicista, pouco orienta os objetos e sujeitos que conformam a vida cotidiana da cidade (em sua totalidade e totalização), sujeitos que a percebem de seus lugares de trânsito e de permanência. Assim, o objetivo do artigo é propor o imaginário, a existência e a cultura como tríade operativa de um planejamento urbano possivel. Metodologicamente, e para defender a tese da predição dialética do imaginário, debatemos (i) a racionalidade instrumental do planejamento e (ii) a centralidade da cultura e da existência em sua revisão, protagonizando o sujeito da e na vida cotidiana urbana. Estabelecemos um diálogo com a ontologia do imaginário de Castoriadis, com a teoria da existência sartriana e com o debate 
crítico frankfurtiano da cultura, além de incorporar uma reflexão mais recente sobre as cidades. Palavras-chave: Planejamento urbano possível; Cultura; Existência; Imaginário; Cotidiano

\section{Resumen}

Planificación urbana posible, imaginario, existencia y cultura

La planificación urbana desde un punto de vista economista y mecanicista apenas guía los objetos y sujetos que conforman la vida cotidiana de la ciudad (en su totalidad y totalización), los cuales la perciben desde sus lugares de tránsito y permanencia. Así, este artículo tiene como objetivo proponer el imaginario, la existencia y la cultura como tríada operativa de una planificación urbana posible. Metodológicamente y para defender la tesis de la predicción dialéctica del imaginario, se debate (i) la racionalidad instrumental de la planificación y (ii) la centralidad de la cultura y la existencia en su revisión, protagonizando el sujeto de la y en la vida cotidiana urbana. Se establece un diálogo con la ontología del imaginario castoridiana, con la teoría de la existencia sartreana y el debate crítico frankfurtiano de la cultura, además de incorporar una reflexión más reciente sobre las ciudades.

Palabras-clave: Planificación urbana posible; Cultura; Existencia; Imaginario; Cotidiano.

\section{Abstract}

Possible urban planning, imaginary, existence and culture

Urban planning from an economist and mechanistic point of view barely guides the objects and subjects that make the daily life of the city (in totality and totalization), which perceive it from their places of transit and permanence. Thus, this essay aims to propose the culture, the existence and the imaginary as an operative triad of possible urban planning. Methodologically, in order to defend the thesis of dialectical prediction of the imaginary, the following are debated: (i) the instrumental rationality of planning and (ii) the centrality of culture and existence in its revision, leading the subject of and in urban daily life. A dialogue is established with the ontology of Castoriadis' imaginary, with the theory of Sartre' existence and the Frankfurtian critical debate on culture, a more recent reflection on cities is also incorporated.

Keywords: Possible urban planning; Culture; Existence; Imaginary; Daily.

Texto recebido em 29/11/2019 e aprovado em 5/8/2020.

DOI: 10.11606/0103-2070.ts.2021.164522.

Everaldo Batista da Costa é professor do Instituto de Ciências Humanas, Departamento de Geografía, da Universidade de Brasília.E-mail: everaldocosta@unb.br 